\title{
Developmental toxicity of cadmium in infants and children: a review
}

\author{
Lalit Chandravanshi ${ }^{1, *(\mathbb{D})}$, Kunal Shiv ${ }^{2}$, and Sudhir Kumar ${ }^{3}$ \\ ${ }^{1}$ Department of Forensic Science, College and Traffic Management- Institute of Road and Traffic Education, Faridabad - \\ Haryana - 121010, India \\ ${ }^{2}$ Division of Forensic Science, School of Basic \& Applied Sciences, Galgotias University Greater Noida - 201306, India \\ ${ }^{3}$ Forensic Science laboratory, Modinagar, Ghaziabad - 201204, India
}

*Correspondence: chandravanshi04@gmail.com

Received: August 31, 2020 Accepted: January 09, 2021

\begin{abstract}
Several millions of people are exposed to cadmium worldwide due to natural and anthropogenic activities that led to their widespread distribution in the environment and have shown potential adverse effects on the kidneys, liver, heart and nervous system. Recently human and animal-based studies have been shown that In utero and early life exposure to cadmium can have serious health issues that are related to the risk of developmental disabilities and other outcomes in adulthood. Since, cadmium crosses the placental barrier and reaches easily to the fetus, even moderate or high-level exposure of this metal during pregnancy could be of serious health consequences which might be reflected either in the children's early or later stages of life. Mortality from various diseases including cancer, cardiovascular, respiratory, kidney and neurological problems, correlation with In utero or early life exposure to cadmium has been found in epidemiological studies. Animal studies with strong evidence of various diseases mostly support for the human studies, as well as suggested a myriad mechanism by which cadmium can interfere with human health and development. More studies are needed to establish the mechanism of cadmium-induced toxicity with environmentally relevant doses in childhood and later life. In this review, we provide a comprehensive examination of the literature addressing potential long- term health issues with In utero and early life exposure to cadmium, as well as correlating with human and animal exposure studies.
\end{abstract}

Keywords: cadmium, developmental neurotoxicity , cognition, kidney dysfunctions

\section{Introduction}

Cadmium is a known environmental carcinogenesis toxicant and also documented as a developmental toxicant [1-2]. Millions of people on the globe are exposed to cadmium from both natural and anthropogenic activities [3-5]. Volcanic eruptions, soil erosion, smelting operations of metal ores, fuel combustion, tobacco smoking, and other various ways are also significantly contributing to introduce cadmium into the environment [6-12]. Once cadmium is released into the environment, it continues to circulate in the human body as cadmium is not being decomposed in nature. High levels of cadmium are naturally present in the air, soil, and water in certain regions of the world, which may enhance the risk of exposure. For the general public, contaminated food and cigarette smoke are the most common routes of cadmium exposure [13-15]. Cadmium could be transferred into the human body via contaminated air, food, and water, accumulated in various vital organs, and produce adverse health effects. Chronic exposure to cadmium has been associated with the development of a various type of diseases in adults, including toxic effects on kidneys, bone, endocrine effects, stomach, lung, prostate cancer and metabolic syndrome [16-21]. Cadmium may affect the mitochondrial functions, apoptosis, cellular activities and genomic instability through complex and multifactorial mechanisms. Cadmium may be impaired the apoptosis, oxidative stress, generation of reactive oxygen species and DNA(Deoxyribonucleic acid) repair mechanism.

Cadmium crosses the placental barrier; therefore, exposure may occur from the beginning of life [22]. In utero or early life development of a child represent a critical window of susceptibility to a toxicant. Any physical or chemical insult at any step during development may lead to developing chronic diseases [23, 24]. Heavy metals may be a serious threat to the development of the fetus and infant health because of their combination of physiological immaturity and longer lifetime exposure during pregnancy and early life can develop chronic disease. At times, the changes are not visible immediately but reflected at later stages of life. The adverse effects during the developmental periods are likely to have long-lasting 
effects and may not recover quite often. Chronic exposure of low-level cadmium may also occur via breast milk and cereals based complementary food, seafood, and vegetables for infants in mostly low-income families. [25-27]. Prenatal and postnatal cadmium exposures have been associated with a variety of adverse pregnancy outcomes including, malformations, decrease fetal growth rate, low birth weight, mortality, further, it may associated with the development of the various disease in children or later life [28-31]. A negative correlation between the cord blood level of cadmium and fetal growth has been observed in cadmium-exposed population in different areas of the world [30,32,33]. Urinary cadmium levels have been measured with Median cadmium concentrations $0.30,0.16$, and $0.30 \mathrm{~g} / \mathrm{L}$ in the urine of 1.5, 5 years, and 3-month-old children. On the other hand, it's also observed that the concentration of cadmium in the infant's urine correlated with concentrations in maternal breast milk, saliva, and urine in a rural area of Bangladesh [34].

Nutritional deficiencies and poor detoxification by affecting the process of methylation are other important factors that may increase the toxicity of cadmium [35]. Population-based studies on children and mothers have reported a correlation between In utero cadmium exposure and cord blood DNA methylation or birth weight [34, 36]). Prenatal chronic exposure to cadmium influence the anthropometric development and growth of the fetus have been linked to later IQ (Intelligence quotient) development in children [34, 37].

A number of epidemiological studies have revealed that In utero and early life chronic exposure to cadmium may cause neurological problems including cognitive deficits, attention deficit hyperactivity disorder (ADHD), social, and attention in young and children [38-40]). Epidemiological studies were also found that children living in an area, contaminated with cadmium even at low exposure levels were associated with enhanced oxidative stress with DNA damage and protein modification in early life and associated with the higher risk of developing cardiovascular disease, osteoporosis and some types of cancer [41-44]. These are some possible mechanisms to monitor associations between In utero or early life cadmium exposure and susceptibility to chronic diseases.

In this review, we organized the study to report, chronic cadmium exposure during In utero and early life and linked with long term health consequences and risk of pregnancy outcomes, neurological, cancer, and renal disease.

\section{Methods}

A literature review has been conducted, using free literature search database 'PubMed' along with 'Google Search Engine. These sources were searched using keywords such as: cadmium or cadmium* and In utero $^{*}$, early life*, prenatal*, postnatal $^{*}$, perinatal ${ }^{*}$, gestational, lactational, developmental ${ }^{*}$, pregnancy outcomes, neurobehavioral, behavior ${ }^{*}$, cognitive dysfunctions IQ* cancer, renal disease, kidney dysfunction etc. All types of appropriate human and animal, studies were considered including journal articles, and reports, with highlighting on recent and more robust studies, and a focus on gestational, lactational, early life and prenatal cadmium exposure. Articles not written in English were expelled.

\section{Pregnancy outcomes}

In utero and early life are very critical and crucial period to toxic agent due to the development of the fetus as structural and functional maturation takes place primarily during this time $[45,46]$. Evaluate the detrimental effects of $I n$ utero and early life cadmium exposure to infants and children are awfully essential. Cadmium is also capable to enter into the fetus at high doses or long-term exposure [22]. Subsequently, the accumulation of cadmium in the placenta has been proven in both experimental and epidemiological studies [47-49]. Various pregnancy outcomes crown-heel length, placental thickness were seen with higher levels of cadmium in maternal blood suggested detrimental effects of exposure on fetal development [30, 33, 50]. Maternal exposure to cadmium in the Saudi Arabian population have revealed that umbilical cord blood cadmium levels were associated with an increased risk of low birth weights, detrimental effects on the head circumference of newborns and also investigated the association between higher levels of cadmium in maternal blood and lower crown-heel lengths [51]. Anomaly in placenta thickness has been directly linked with retarded intrauterine fetal growth. Prenatal exposure to cadmium resulting in placental dysfunctions associated with lower birth weights and fetal growth $[50,52,53]$. High level of cadmium in the placenta and umbilical cord blood can be a risk factor for subsequent impairment in developmental infants or influenced child growth later in life [53,54]. It is also proved that cadmium is also accumulated via breast milk postnatally, and these levels of cadmium might be a possible potential health hazard to fetuses and neonates [30]. Concentrations of oleic, elaidic, and cis-vaccenic acids in the breast milk of cadmium-exposed women might suggest the increased cadmium toxicity to the infant, taking into consideration even low cadmium passage to milk [55]. Maternal cadmium exposure during earlier periods of pregnancy was inversely associated with birth weight and ponderal index which indicates the delayed pattern of fetal growth [56].

With respect to human studies in Taiwan maternal and cord-blood cadmium was found to be associated with a significantly decreased head circumference at birth and also described subsequent child grow up to first 3 years of life is associated with a decrease in height, weight and head circumference [53]. Inverse association between prenatal cadmium exposure and both fetal and child growth has also been observed in this study. Cadmium exposure during intrauterine 
influences fetal growth may induce carcinoma either through hyper and hypo DNA methylation [36, 57, 58]). A recent population-based prospective study of 319 infant-mother pairs in Durham, USA was carried out to measure maternal cadmium levels during early pregnancy and DNA methylation at regulatory differentially methylated regions in infants, which is associated with the lower birth weight. Reduced levels of zinc are also found in this study that may moderate these effects. Further higher maternal cadmium blood levels were also associated with lower methylation at the PEG3 DMR in females and at the MEG3 DMR in male offspring. Associations between cadmium and PEG3 and PLAGL1 DNA methylation were significant in infants born to women with low concentrations of Iron (Fe) [59]. Sex-specific modification in DNA methylation was found in the fetal blood, where women are exposed to the low level of cadmium during pregnancy in Bangladesh [34]. Impairment in the DNA methylation in the cord blood was closely linked with the maternal blood cadmium concentrations.

Cadmium concentrations have been analyzed in the cord blood, maternal blood, and placental tissue with cadmium-induced oxidative stress that adversely affects the birth outcome [32] and spontaneous abortion [60]. Leptin as a biomarker of metabolic dysfunctions has been researched in different populations. A significant relationship between maternal blood cadmium and high level of fetal leptin suggests that prenatal exposure to cadmium may impair fetal metabolic development [61]. This evidence is also demonstrating the susceptibility of prenatal cadmium exposure to the fetal development and growth of the children. A study in Da-Ye Country, Hubei Province in Central China pregnancy outcome, and developmental adverse effect on offspring data of 109 pregnant women and 106 children up to 4.5 years of age were related to In utero cadmium exposure [52]. After the multiple linear regression analysis points out that cord blood cadmium level was significantly negatively linked with low fetus development and later IQ development in children.

Loss of body weight, various pregnancy outcomes, and impairment in anthropometric measurement following In utero and early life exposure to cadmium were observed in human and animal study indicates growth impairment and exhibit the vulnerability of developing infants. In most of the cases, infant mortality and birth outcomes were increased with the increasing level of cadmium in cord blood, maternal blood, and placental tissue [62]. Fetal growth is also influenced by various factors including maternal nutrition, genetic variability, and social status. The mechanisms by which cadmium induces low birth weight and infant growth are not well understood. Of the various concerns, In utero and early life exposure to cadmium has been shown that various pregnancy outcomes including the low birth weight of infants. Further, it may be associated with adverse neurodevelopmental outcomes [63].

\section{Neurobehavioural and cognitive dysfunctions}

Cadmium has been categorized as potential developmental neurotoxicant due to its ability to crosses the placental and blood-brain barrier [64,65]. Therefore cadmium reaches the fetus and the brain during early development stages of fetus or children [53]. It has been suggested that cadmium directly affects the development of the central nervous system[3, 66] and associated with behavioral and cognitive dysfunction, including poor learning memory in children during early life [2, 52, 67-69]. Cadmium levels are measured in the umbilical cord blood, maternal urine, and placenta of women, after the In utero exposure that is correlated with the adverse pregnancy outcomes and infants' health. Subsequently, urine and hair are the most useful matrices to establish the association between cadmium levels and neurobehavioural dysfunctions in the children $[70,71]$.

Cadmium low-level exposure, found in U.S. children (6-15 years old) as per NHANES (National Health and Nutrition Examination Survey) relates the level of urinary cadmium to learning disabilities and attention deficit hyperactivity disorder, this being stronger in boys [2]. A growing number of studies suggested that low to moderate levels of cadmium is associated with neuropsychological development, neurological and cognitive dysfunctions, especially in verbal IQ in children [5, 72, 73]. In the Korean study, the authors evaluated the IQ performance of children by using the Wechsler Preschool and Primary Scale of Intelligence methods (WPPSI-R) at 60 months of age and successfully drawn a correlation between maternal blood cadmium concentration and lower IQ in children [37]. Gustin et al. 2018 was also reported that the adverse impact of prenatal and childhood cadmium exposure on children's cognitive behavior and the few associations observed were more pronounced in girls than in boys [74].

Neuropsychological development and behavioral assessment were followed by Wechsler Intelligence Scale, reaction time test, continuous performance test and selective attention test performed on children living in a coastal industrialized region in southwestern Spain, the results show an opposite association between urine cadmium level and verbal comprehension, had similar potency in both boys and girls [73]. Further, in this study, early life exposure was not associated with hair cadmium levels with neuropsychological development in children but gender-specific results have also occurred in this study. Full-scale IQ and verbal comprehension and perceptual reasoning domain results show the negative association with cadmium exposure in boys, but not among girls. Several cross-sectional studies have been conducted in cadmium contaminated areas reported associations between cadmium exposure and impairment in verbal IQ and visualmotor and cognitive tasks of children [75, 76]. In many case-control studies, have been found to mental retardation [77] and learning difficulties or dyslexia [78] in children with exposure to a high concentration of cadmium. 


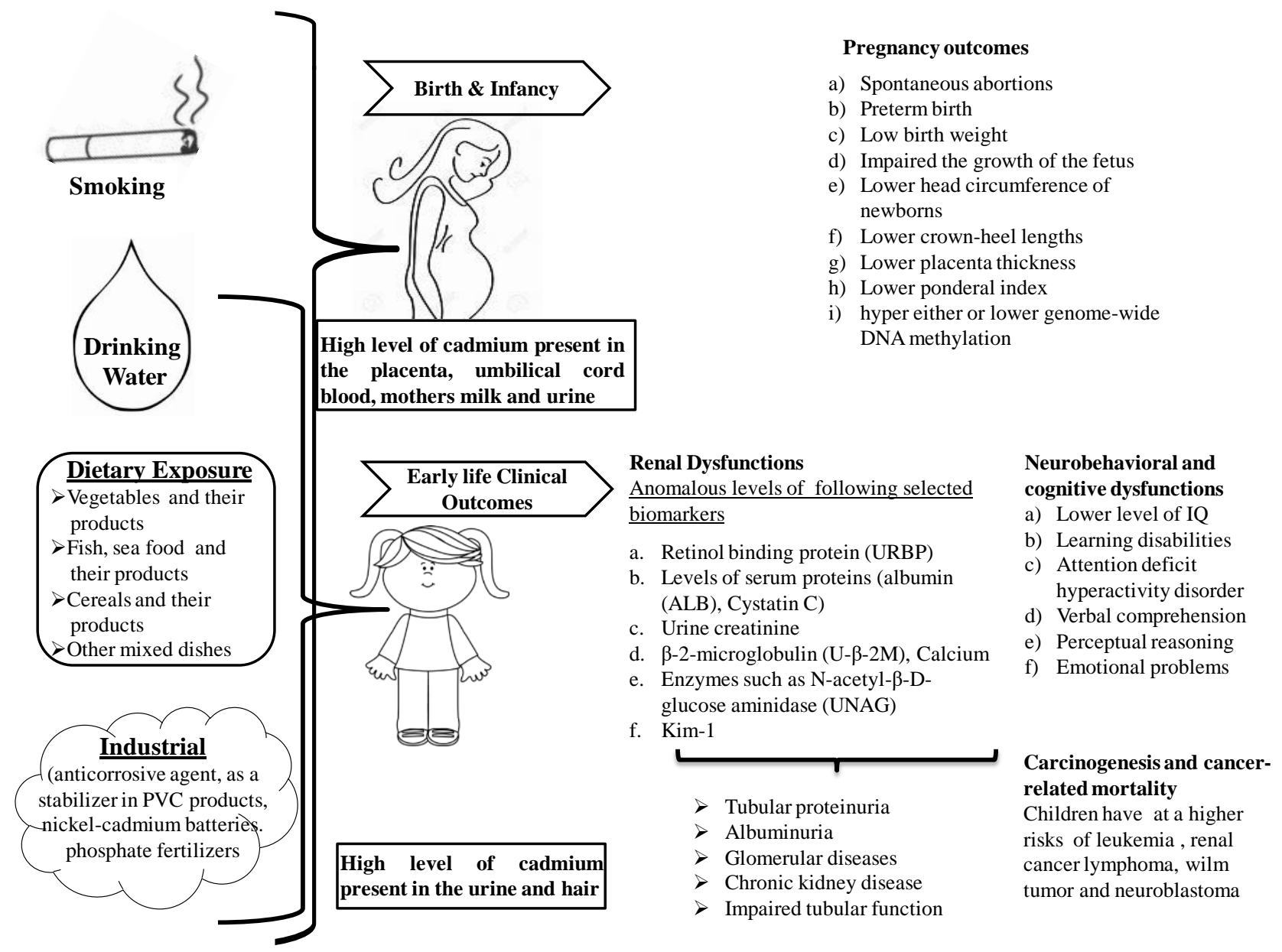

Figure 1. In humans, exposure to cadmium is associated with adverse health effects. Cadmium In utero or in early life also produces adverse various health effects in infants and children that consumed contaminant different sources of cadmium. In utero cadmium exposure may lead to different pregnancy outcomes and poor infant health (top) and early life exposure to cadmium demonstrate that adverse health effects in children (bottom). These clinical outcomes may link the significant presence of cadmium in the umbilical cord blood, mother's milk and urine of both women and children. Examination of clinically relevant adverse outcomes may help to elucidate cadmium-related pathogenesis and later-life disease susceptibility.

Bao et al. (2009) conducted an ecologic study to the assessment of behavioral disorders and found a higher frequency of withdrawal, social problems and attention problems associated with higher hair cadmium levels in Chinese children aged 7-16 years, who lived in the Hengshihe area that had different degrees of heavy-metal pollution [79]. In a follow-up study conducted by [80] in Bangladesh, cadmium exposure was assessed through the urine of pregnant women (1, 305 women) and the hair of their children at 5 years of age. An inverse statistically significant relationship has been observed between cadmium levels in maternal urine during early pregnancy and verbal or full-scale IQ performance in both genders [80].

These associations are stronger in girls than in boys. Cadmium levels in the hair of children pertaining to the early life effects of cadmium exposure, a significant correlation was found with performance and full-scale IQ only in females. With respect to behavioral studies, Sioen et al. (2013) conducted a cross-sectional study on children at $7-8$ years of age in Belgium and found 1.53 times higher risk for emotional problems in boys were associated with doubling cord blood cadmium, whereas no such significant association was found in girls [81]. Cao et al. (2009) assessed the IQ of children at 5 and 7 years of age, but the association with 2-year blood cadmium levels was not statistically significant [3]. Maternal blood concentration of cadmium during the early pregnancy period had not significantly associated with mental (MDI) and psychomotor (PDI) development index scores of the infants at 6 months of age [82]. The association was not significant with prenatal cadmium and McCarthy Scales of Children Abilities (MSCA) measure of cognition in 4-year-olds children in Spain [83] but these ecological studies suggested that cadmium may also have a detrimental effect on neurodevelopment during 
In utero and early life exposure.

Cadmium has been associated with behavioral and cognitive dysfunctions in children and neurodevelopment abnormalities in infants during In utero or early life exposure [40]. Few clinical studies have been proved that cadmium may also act as an endocrine disruptor, influence the estrogens, thyroid, and growth hormones, all of which have a significant role in brain development during In utero or early life [84-86]. It is difficult to explain on the range of cadmium in maternal blood, maternal urine, placenta, cord blood, and child's urine, hair cadmium level with neurodevelopment outcomes, neurobehavioural and cognitive dysfunctions.

Many experimental studies have revealed that prenatal exposure to cadmium may affect the normal development of progeny and brain functions during early life [87-90]. A study by Minetti et al. (2006) showed altered the gabaergic and serotonergic neurotransmission process along with anxiety behavior deficits in rat pups exposed to cadmium during the gestational period. In addition, this prenatal cadmium exposure leads to a delay in the development of the righting reflex, and the cliff aversion in the offspring, indicate that gestational cadmium exposure may modify the functions of the brain [87]. Cadmium is accumulated in the placenta, resulting in alter with the zinc, other essential elements and nutrients during the period of neurulation [90-93] with a wide range of cellular, neurochemical, neurotoxicological, and behavioral alterations in neonatal rats after the cadmium exposure through the mother [66, 94, 95]. Zhang et al. (2009) had reported enhancement of the oxidative stress (due to decrease in the activity of SOD (Superoxide Dismutase), CAT (Catalase), GSH-Px(Glutathione Peroxidase), the increase in MDA (maleic dialdehyde) levels) in the brain of rat pups after the administration of cadmium chloride led to impair the functions and ultrastructure of the central nervous system, which may contribute to elucidate the possible mechanisms of cadmium-induced developmental neurotoxicity in rats [96]. In addition, the long term exposure of cadmium and interaction with other metals such as cobalt and zinc leads to epigenetic modification and estrogen-like effect which may be associated with the mechanism of neurotoxicity [97-101].

\section{Renal Dysfunctions}

Cadmium accumulates in various tissues and organs of the human body, especially in the kidney due to its long biological half-life, hence known to be the main site of cadmium burden in older children [102]. Urine cadmium (U-Cd) concentration, which is a well-accepted biomarker to long-term cadmium exposure in humans suggested that kidney dysfunctions are associated with the accumulation of cadmium [103, 104]. High concentrations of cadmium in the urine of infants, demonstrating the lower kidney accumulation of cadmium due to higher rates of urinary excretion in infants compare to later in adult life [80, 105].

The developing kidney is more at risk to cadmium than the adult, as glomerular and tubular functions continue to develop until 2-3 years of age [106]. Proximal tubules are the main sites of cadmium accumulation where primarily affects is on cellular and the functional integrity of the proximal tubules [107]. A lot of concerns are available to cadmium-induced nephrotoxicity in adults. Knowledge of such an effect on children is very scanty as reported in human and animal studies $[80,108,109]$. The presence of cadmium in the blood might affect the renal glomerular endothelial cells barrier integrity and lead to the development of clinical signs of glomerular diseases [110]. In the kidney, the cortex is found to be the main site for the accumulation of Cadmium. Cadmium exposure may have a detrimental effect on tubular re-absorption of renal function during childhood. Possible early signs of renal dysfunction at a low level of cadmium exposure are decreased glomerular filtration rate and increased urinary loss of tubular enzymes [111- 113].

There are several predictable biomarkers for cadmium-induced kidney dysfunction. Increased urine excretion of these proteins (urinary beta-2-microglobulin (UB2M) and retinol-binding protein (URBP) and N-acetyl- $\beta$-D-glucose aminidase (UNAG) indicates kidney tubular damage [24, 104, 108, 114, 115]. Levels of serum proteins (albumin (ALB), Cystatin C) in the urine are increased appear to be linked with renal glomerular damage [45, 116]. These are well established renal damage biomarkers for cadmium exposed population which is linked with the level of cadmium in urine or blood [80, $117,118]$. 
Table 1: Characteristics of different studies of cadmium exposure during In utero or early life exposure and children's developmental outcomes

\begin{tabular}{|c|c|c|c|c|c|c|c|}
\hline Location & $\begin{array}{c}\text { Author and } \\
\text { Year of } \\
\text { Publication }\end{array}$ & $\begin{array}{l}\text { Study } \\
\text { design }\end{array}$ & $\begin{array}{c}\text { Study } \\
\text { Population } \\
\text { Size(n) } \\
\end{array}$ & Age & Exposure Metrics & $\begin{array}{l}\text { Exposure Levels } \\
\text { (mean) }\end{array}$ & Developmental Outcomes \\
\hline China & $\begin{array}{l}\text { Wang et al. } \\
\qquad 2018\end{array}$ & $\begin{array}{l}\text { case- } \\
\text { control } \\
\text { study }\end{array}$ & $\begin{array}{l}\text { 132pregnant } \\
\text { women }\end{array}$ & $\begin{array}{c}\text { Healthy Pregnant } \\
\text { women's: } 26.97 \pm \\
2.94 \\
\text { Preeclampsia } \\
\text { women's: }=26.33 \pm \\
3.96 \\
\end{array}$ & $\begin{array}{c}\text { maternal blood } \\
\text { umbilical cord blood } \\
\text { placenta }\end{array}$ & $\begin{array}{l}1.21 \mu \mathrm{g} / \mathrm{L} \\
1.09 \mu \mathrm{g} / \mathrm{L} \\
4.28 \mu \mathrm{g} / \mathrm{kg}\end{array}$ & $\begin{array}{c}\text { Preeclampsia } \\
\text { Fetal growth restriction }\end{array}$ \\
\hline France & $\begin{array}{l}\text { Menai M et al. } \\
2016\end{array}$ & $\begin{array}{l}\text { cohort } \\
\text { study }\end{array}$ & $\begin{array}{l}901 \text { pregnant } \\
\text { women }\end{array}$ & 18- to 45 -years old & $\begin{array}{l}\text { maternal blood } \\
\text { cord blood Cd }\end{array}$ & $\begin{array}{l}0.55 \pm 0.42 \mathrm{~g} / \mathrm{L} \\
0.88 \pm 0.59 \mathrm{~g} / \mathrm{L}\end{array}$ & $\begin{array}{l}\text { reduced birth weight } \\
\text { Fetal growth restriction }\end{array}$ \\
\hline $\begin{array}{l}\text { Heraklion, } \\
\text { Greece }\end{array}$ & $\begin{array}{l}\text { Chatzi et al. } \\
2019\end{array}$ & $\begin{array}{l}\text { cohort } \\
\text { study }\end{array}$ & $\begin{array}{l}515 \text { mother- } \\
\text { child pairs }\end{array}$ & $\begin{array}{l}9 \text { months, } 18 \\
\text { months, and } 4 \text { years } \\
\text { of age of child's }\end{array}$ & urinary cadmium & $0.571-2.658 \mu \mathrm{g} / \mathrm{L}$ & $\begin{array}{c}\text { slower weight trajectory in childrens } \\
\text { slower height trajectory in girls }\end{array}$ \\
\hline $\begin{array}{l}\text { Szczecin, } \\
\text { Poland }\end{array}$ & $\begin{array}{l}\text { Olszowski T et } \\
\text { al. } 2016\end{array}$ & $\begin{array}{l}\text { cohort } \\
\text { study }\end{array}$ & $\begin{array}{c}75 \text { mother- } \\
\text { newborn } \\
\text { pairs }\end{array}$ & $\begin{array}{c}\text { women's } 28.23 \pm \\
4.85 \text { years }\end{array}$ & $\begin{array}{c}\text { maternal blood } \\
\text { newborn's blood } \\
\text { breast milk }\end{array}$ & $\begin{array}{l}0.61 \pm 0.62 \mu \mathrm{g} / \mathrm{L} \\
0.05 \pm 0.04 \mu \mathrm{g} / \mathrm{L} \\
0.11 \pm 0.07 \mu \mathrm{g} / \mathrm{L}\end{array}$ & $\begin{array}{l}\text { oleic, elaidic, and cis-vaccenic acids } \\
\text { in breast milk }\end{array}$ \\
\hline $\begin{array}{c}\text { Szczecin, } \\
\text { Poland }\end{array}$ & $\begin{array}{c}\text { Szkup- } \\
\text { Jabłońska M et } \\
\text { al. } 2012\end{array}$ & $\begin{array}{l}\text { cohort } \\
\text { study }\end{array}$ & $\begin{array}{l}78 \text { children - } \\
16 \text { girls and } 62 \\
\text { boys }\end{array}$ & $\begin{array}{c}\text { mean age of } \\
\text { children: } 8 \text { years }\end{array}$ & $\begin{array}{c}\text { mean blood cadmium } \\
\text { level }\end{array}$ & $0.215 \mu \mathrm{g} / \mathrm{L}$ & $\begin{array}{l}\text { Attention deficit disorder } \\
\text { hyperactivity and impulsive } \\
\text { behaviour }\end{array}$ \\
\hline U.S & $\begin{array}{c}\text { Ciesielski T et } \\
\text { al. } 2012\end{array}$ & $\begin{array}{l}\text { cohort } \\
\text { study }\end{array}$ & 2,195 children & $\begin{array}{c}\text { 6-15 years of age of } \\
\text { children }\end{array}$ & urinary cadmium & $0.130 \mu \mathrm{g} / \mathrm{L}$ & learning disability \\
\hline $\begin{array}{c}\text { Seoul, } \\
\text { Cheonan, } \\
\text { Ulsan, } \\
\text { South } \\
\text { Korea }\end{array}$ & $\begin{array}{l}\text { Jeong KS et al. } \\
\qquad 2015\end{array}$ & $\begin{array}{l}\text { cohort } \\
\text { study }\end{array}$ & $\begin{array}{l}119 \text { children } \\
\text { and mothers }\end{array}$ & $\begin{array}{l}5 \text { years of age of } \\
\text { children }\end{array}$ & Maternal blood & $1.51 \pm 0.36 \mu \mathrm{g} / \mathrm{L}$ & Low Performance IQ \\
\hline $\begin{array}{c}\text { Heraklion, } \\
\text { Greece }\end{array}$ & $\begin{array}{l}\text { Kippler M } \\
\text { et al.2016 }\end{array}$ & $\begin{array}{l}\text { cohort } \\
\text { study }\end{array}$ & $\begin{array}{l}575 \text { mother- } \\
\text { child pairs }\end{array}$ & $\begin{array}{c}\text { children at } 9,18 \\
\text { months, and } 4 \text { years } \\
\text { of age }\end{array}$ & $\begin{array}{l}\text { Materanal urinary } \\
\text { cadmium }\end{array}$ & $2.9 \mu \mathrm{g} / \mathrm{L}$ & Low Cognitive scores \\
\hline $\begin{array}{l}\text { Jiangsu } \\
\text { Province, } \\
\text { China }\end{array}$ & $\begin{array}{c}\text { Zhou T et al. } \\
2020\end{array}$ & $\begin{array}{l}\text { cohort } \\
\text { study }\end{array}$ & 296 Chidren & $\begin{array}{l}\text { mothers were less } \\
\text { than } 25 \text { years old at } \\
\text { delivery and school } \\
\text { age children }\end{array}$ & $\begin{array}{l}\text { Umbilical cord blood } \\
\text { urinary cadmium }\end{array}$ & $\begin{array}{l}63.85 \mu \mathrm{g} / \mathrm{L} \\
88.85 \mu \mathrm{g} / \mathrm{L}\end{array}$ & $\begin{array}{c}\text { lower IQ and } \\
\text { performance IQ }\end{array}$ \\
\hline Belgium & $\begin{array}{c}\text { Wang } \mathrm{H} \text { et } \\
\text { al.2107 }\end{array}$ & $\begin{array}{l}\text { cross- } \\
\text { sectiona } \\
\text { l study }\end{array}$ & $\begin{array}{c}249 \\
\text { schoolchildre } \\
n \\
\text { (138 boys, } 111 \\
\text { Girls) }\end{array}$ & $\begin{array}{c}\text { mean age, } 5.72 \\
\text { years }\end{array}$ & $\begin{array}{l}\text { Boys urinary cadmium } \\
\text { Girls urinary } \\
\text { cadmium }\end{array}$ & $\begin{array}{l}0.22 \mu \mathrm{g} / \mathrm{L} \\
0.24 \mu \mathrm{g} / \mathrm{L}\end{array}$ & renal and developmental effects \\
\hline Thialand & $\begin{array}{l}\text { Swaddiwudhip } \\
\text { ong W et al. } \\
2015\end{array}$ & $\begin{array}{l}\text { cross- } \\
\text { sectiona } \\
\text { l study }\end{array}$ & $\begin{array}{l}594 \text { primary } \\
\text { school } \\
\text { children }\end{array}$ & $\begin{array}{c}\text { Mean Age } 9.4 \pm 1.9 \\
\text { Years }\end{array}$ & $\begin{array}{l}\text { Blood cadmium } \\
\text { Urinary cadmium }\end{array}$ & $\begin{array}{l}2.42 \mu \mathrm{g} / \mathrm{L} \\
0.57 \mu \mathrm{g} / \mathrm{L}\end{array}$ & $\begin{array}{l}\text { urinary excretion of } \beta 2-\mathrm{MG} \text {, calcium } \\
\text { (early renal effects), and urinary } \\
\text { total protein (late renal effect) }\end{array}$ \\
\hline Bangladesh & $\begin{array}{c}\text { Skroder H et al. } \\
2015 \\
\end{array}$ & $\begin{array}{l}\text { cohort } \\
\text { study }\end{array}$ & $\begin{array}{c}1106 \\
\text { children }\end{array}$ & 4.4-5.4 year & Urinary cadmium & $0.5 \mu \mathrm{g} / \mathrm{L}$ & Decease glomerular filtration rate \\
\hline $\begin{array}{l}\text { Torreón, } \\
\text { Mexico }\end{array}$ & $\begin{array}{c}\text { Weaver MV et } \\
\text { al. } 2014\end{array}$ & $\begin{array}{l}\text { cross- } \\
\text { sectiona } \\
\text { l study }\end{array}$ & $\begin{array}{c}512 \\
\text { adolescents. }\end{array}$ & $\begin{array}{c}\text { Median Age: } 13.9 \\
\text { years }\end{array}$ & Urinary cadmium & $\begin{array}{c}0.22 \mathrm{~g} / \mathrm{g} \\
\text { creatinine }\end{array}$ & Decease glomerular filtration rate \\
\hline
\end{tabular}


Adverse effects on the renal system have been found in different cadmium-exposed children around the world, including Bangladesh, USA, Belgium, Poland, Romania, Hungary, Germany, and Spain [80, 119]. Only a few research papers have reported on renal diseases in early life with respect to environmental cadmium chronic exposure at low and high doses. The incidence of renal diseases was found to be increased in 12 European countries studied under the DEMOCOPHES project and established a significant correlation between urine cadmium (range0.10-0.69 $\mu \mathrm{g} / \mathrm{L}$ ) and creatinine, higher than the reference value in all age groups (6 to 11 year) for both genders (boys and girls) [119]. DEMOCOPHES project finding shows that cadmium may cause a disturbance in kidney functions even at low levels of exposure and further results, clarify a higher risk of kidney damage in girls than in boys. Long term exposure to cadmium causes albuminuria and chronic kidney disease with a median range of cadmium level above $1 \mu \mathrm{g} / \mathrm{L}$ in adults [120]. Cystatin $\mathrm{C}$ is another biomarker to assess the effect of cadmium on kidney function [45]. A large cohort study of rural Bangladeshi preschool-aged children have shown the potential long-term consequences and found that the link between eGFR and cystatin C level was mainly seen in the girls. Regression analysis after the adjusted multivariable revealed that the urinary cadmium level is inversely associated with eGFR in children with low concentrations of selenium. However, this association was more pronounced in girls than boys and the slightly weaker inverse correlation between cadmium exposure and kidney volume was also observed [121]. Weaver et al. (2014) have reported a positive association of urine cadmium $(0.22 \mathrm{~g} / \mathrm{g}$ creatinine $)$ with serum creatinine-based eGFR, adjusted with urine creatinine, however poor relation between urine and serum cystatin-C-based eGFR have also been addressed in USA adolescents. No consistent evidence of nephrotoxicity was observed in this study [122].

In a cross-sectional study of 594 primary school children exposed to cadmium in Thailand, urinary levels of cadmium (U-Cd level, $5 \mu \mathrm{g} / \mathrm{g}$ creatinine) were associated with the increased levels of $\beta 2$-microglobulin, and calcium but not with urinary total protein. In view of this study confirmed that environmental cadmium exposure can impair kidney functions in children [123]. Tubular proteinuria is an early sign of cadmium-induced nephrotoxicity, generally confirmed by an increase in the excretion of $\beta 2$-microglobulin, calcium, and enzymes such as N-acetyl- $\beta$-D-glucose aminidase [5, 17, $18,107,124]$. The association of urine cadmium $(0.26 \mu \mathrm{g} / \mathrm{g}$ creatinine $)$ with urinary albumin level has been found in children aged from 6 to 17 years, but this association turns in to be insignificant after adjusted creatinine and other potential confounders [125]. The presence of albumin protein in the urine gives a sign of an increase in the permeability of the glomerular filtration barrier thereby impaired the reabsorption rate of filtered proteins. Impaired tubular function, indicated by higher excretion of urine $\beta$-2-microglobulin $(\mathrm{U}-\beta-2 \mathrm{M})$ and retinol-binding protein (U-RBP), has been found in former children's long term exposure to environmental cadmium during early life than in the unexposed adults. This study was a follow-up of the 1991-1994 project by Trzcinka-Ochocka, et al. (2004) point out that children are more susceptible to kidney dysfunction than adults who were born and grew up at the cadmium-contaminated area in the vicinity of a zinc smelter in Poland [106]. Cross-sectional European survey on 800 children, those living around historical nonferrous smelters in France, the Czech Republic, and Poland had found the appearance of Clara cell protein and N-acetyl- $\beta$-D-glucosaminidase were associated with blood or urine cadmium levels indicate that subtle tubular effects on the kidney [108]. Exposure and accumulation of Cadmium begin at a young age, mainly in the kidney cortex and major source for Cd exposure in children is through food. The pertinacious nature of this metal in the environment needs a long-term step to minimize human exposure through proper environmental management [126]. Ruiz et al. (2010) used the computerized models for assessing the health risk to monitor the urine cadmium level among 6-11-year age group of children, for both genders and found approximately twofold higher U-Cd level among females than males in all age groups [127]. Urinary and blood cadmium level has been found to associate with renal dysfunctions biomarker in early life exposed children's and suggest that the chronic exposure to cadmium even low at dose may widen the chronic kidney diseases in later life.

Several animal studies have evaluated the association between cadmium exposure and the risk of kidney functions during In utero or early life [128-130]. An In-vivo study demonstrated that accumulation of cadmium increases in the kidney from postnatal day 2 to postnatal day 60, where rats were exposed to cadmium through mother during the gestational period [130]. Glomerular filtration was not appearing to get significantly affected until PD45 (postnatal day 45). However, glomerular filtration rate significantly decreased and was associated with an increase in the excretion of the $\mathrm{Na}^{+}$ (Sodium), $\mathrm{K}^{+}$(Potassium), $\mathrm{Mg}^{2+}$ (Magnesium), $\mathrm{Ca}^{2+}$ (calcium) ions on PD60 (postnatal day 60). The presence of cadmium in the milk of rats confirmed that pups were also exposed to cadmium via breast milk during postnatal development [130]. In utero cadmium exposure to rats shows a remarkable decrease in the activity of alkaline and acid phosphatases, $\mathrm{Mg}^{2+} / \mathrm{Ca}^{2+}$ dependent ATPase, and $\mathrm{Na}^{+} / \mathrm{K}^{+}$- dependent ATPase indicating that cadmium is able to impair the renal functions [131]. The activity of these enzymes is related to the functions of the kidney such as re-absorption and secretion processes and differentiation of the proximal tubules. KIM-1 (kidney injury molecule-1) is a transmembrane protein highly expressed in kidney excreted into the urine and only after any toxic insults, but not normally detected in the kidney [132-134]. Increased mRNA expression of KIM-1 in the kidney has been reported in both directly cadmium oxide nanoparticles exposed to pregnant females and their newborn offspring [135]. Cadmium-induced renal dysfunctions were associated with the biochemical, anatomical, functional, and physiological changes of a kidney, suggesting that long term exposure to cadmium during In utero or early life may produce systemic nephrotoxic effects. Cadmium may have a strong impact on renal functions in children as compared to adults. 


\section{Carcinogenesis and cancer-related mortality}

Cadmium is an established human carcinogen, first classified by the International Agency for Research on Cancer [136]. Several occupational studies have been found that chronic cadmium exposure can induce cancer mortality, including breast, lung, prostate, pancreatic and renal cancers [137-140]. To date, almost all published studies linking Cadmium exposure with carcinogenesis have reported a high risk of cancer in adults and very less in children. The evidence of cancer risk in children caused by cadmium exposure appears to be well supported by epidemiological (cohort, case-control) studies. An underlying relation between cadmium in air pollution and cancer incidence rate was observed in children of Poland under 18 years of age during the 1995-2004 periods. With respect to this study very weak coefficient correlation (0.1-0.3) was reported between the numbers of reported cases of cancer in boys with cadmium-related environmental pollution and no such correlation has been found in the case of girls, whereas children were exposed to cadmium during In utero and early life stage [141]. Leukemia risks of childhood were slightly increased from exposure to cadmium through contaminated drinking water with other toxicants during the postnatal period [142]. A large case-control study in Egypt, with 350 pediatric cancer cases aged 3 to 14-years old and 350 control healthy children have demonstrated a significant correlation of cadmium level (blood, urine, scalp hair, and nails) in different cancer cases (leukemia, lymphoma, wilm tumor, neuroblastoma, rhabdomyosarcoma, brain tumors, and teratomas) $(\mathrm{P}<0.001)$ compared to the controls [143]. The association between cadmium exposure and pediatric malignancy was reported more frequently with tobacco smoke exposure, rural residence, and low socioeconomic status when compared with controls. Pancreatic cancer patients living in rural areas compared with controls have been consistently found in Dakahlia, Egypt with the high-level of cadmium in serum [144].

However, findings of the studies have added the other additional factors such as co-exposure to other toxic heavy metals, chemicals, and lifestyle in cadmium-induced carcinogenesis [25, 141, 145, 146]. Genetic and other environmental factors may also appear to be a significant contributor to the incidence of cancer and the progress of diseases [147-148]. An additional important question is also raised that the difference in the incidence rate of cancer in rural and urban areas that might be an interesting environmental study. Nutritional deficiencies chiefly calcium, zinc, and iron are a more susceptible factor among low socioeconomic children suggested that it is an important cofactor for cadmium accumulation in tissues and increasing incidence of their hazards and thereby indicates the involvement of nutritional deficiencies in the risk of malignancy [91, 146, 149]. The relationship between iron deficiency (ID) and the concentration of blood cadmium was investigated and shared the neurotoxic effects in U.S. children aged 3-19 years [150] Smoking is another important factor to contribute to the development of cancer with an increase the accumulation of cadmium in individuals who smoke cigarettes and the strong the relation between cancer and smoking [18, 151].

In addition to clinical studies, a number of experimental studies were conducted during early life and In utero cadmium exposure in rodents to establish cadmium-induced carcinogenesis [152, 153]. Multiple rodent studies have confirmed that cadmium exposure develop various types of cancer by multiple mechanisms including endocrine disruption [154, 155], induction of oxidative stress, generation of reactive oxygen and nitrogen species (ROS/RNS) [156], inhibition of DNA damage repair, inflammation $[157,158]$ and inhibition of apoptosis [159]. Cadmium may also promote carcinogenesis by aberrant gene expression, cell proliferation, and differentiation [160, 161] DNA base modifications [162].

\section{Summary and conclusion}

Human and animal database supports that cadmium is an environmental toxicant, which has a greater susceptibility for the fetus and children as a result of exposures during In utero and early life. The information on In utero and early life cadmium exposure in terms of the high risk of kidney diseases, pregnancy outcomes, impairment in neurodevelopment, cancer, and other diseases through various modes of action, showing more susceptibility to a critical period of development of the organ in fetus or children. Of various mechanistic pathways through which cadmium has the ability to change the physiological, functional, and structural of different organs of the body during In utero or early life exposure. A growing body of literature In utero or early exposure of cadmium on both animals and humans suggests that cadmium concentration in urine, blood, and hair has been linked with adverse health effects in fetuses or children [163], [164]. Prenatal cadmium exposure has been assessed by the measured levels of cadmium in cord blood or placenta and thereby indicates the maternal cadmium burden and fetal growth [80]. There is various epidemiological evidence that the kidney is a major target organ to cadmium exposure due to the long half-life of cadmium in the kidney (10-30 years) relative to that other system. Long-term exposure to cadmium during In utero and early exposure suggested that cadmium has the capability to produce neurological deficits, along with behavior modifications, which are observed in clinical and experimental studies. Data on In utero cadmium exposure with neurological problems is very limited so far and more research is needed. In utero and early life cadmium exposure in relation to long-term health consequences may also be associated with genetic and environmental factors. In spite of chemical, social, or other nutritional factors are including additional factors of sex, smoking, alcohol consumption, and exposure to mixtures known to influence the susceptibility to the adverse effects of cadmium. The timing of exposure is a very important factor to identify the intensity of the effects and whether these factors will interact with it. Most of the published reports do not provide the exact duration in which peoples 
were exposed to cadmium. Smoking is the main factor to influence the toxicity of cadmium as cigarette has a significant additional amount of cadmium [68]. The mechanisms by which cadmium might delay the anthropometric development and growth of the fetus are not well recognized. However, enhanced oxidative stress, inhibition of DNA repair with altered DNA methylation, protein modification in cord blood or placental tissue has been linked with the adverse effect on pregnancy outcomes and fetus growth $[32,59,64]$. Ecological studies have also shown that cadmium may act as influence the estrogens, thyroid endocrine, and growth hormone system during In utero and early life exposure [85, 86]. Cadmium may also directly or indirectly affect the normal growth of vital organs, including the nervous system during intrauterine life via several feasible approaches. Accumulation of cadmium in the placenta may decrease the transportation of trace elements (Fe, Mn, Zn, Mo, Cu) to the fetus, due to cadmium interaction with trace element metabolism through a different mechanism that is not well known $[48,156,165]$. Zinc and iron are very essential metals for the development of the brain and other systems during the developing period of fetuses and children. Decreases in the normal levels of zinc, iron, and copper have been found to be linked with an increase in the content of cadmium. In addition, increase the urinary excretion of some essential metals, such as copper, zinc, and iron has been observed in the cadmium-exposed population [166, 167]. High concentrations of kidney cadmium in the Jamaican population may be related to hypocupraemia and is associated with the high cadmium pollution area [168]. Many experimental studies have shown that antagonistic interaction between cadmium and selenium, but an association between selenium and cadmium burden in concerning children and pregnant women is very scanty, and therefore more research is needed for the interaction of cadmium with selenium [169].

Chronic exposure to cadmium to be continuing for millions of people's world widely via multiple sources like smoking of cigarettes, consumption of cadmium contaminated cereals including rice and its products, fishes, and cosmetic products may be a common source of cadmium exposure. Direct assessment of the condition of a family, including the education level of parents and other multiple factors as well as genetic influences with cadmium exposure could not be completely ruled out in most of the ecological studies. Consequently, more research will have to require further investigation of potential long-term health consequences In utero and early life exposure to cadmium and its interaction with environmental and genetic factors. Different patterns of cadmium exposure for intrauterine and early life stages and interact with the environment through which different the way would identify. This approach will help to establish the mechanism and pathways for the relationship between cadmium exposure and health effect in pediatric populations and also provide the information to implement environmental management strategies for better cautiousness or vigilance and management of cadmium associated health effects, especially in children.

\section{Conflict of interest}

Conflict of Interest Lalit P Chandravanshi, Kunal Shiv and Sudhir Kumar declare that they have no conflict of interest. This article does not contain any studies with human or animal subjects performed by any of the authors.

\section{CRediT author statement}

LC: Ideas; Methodology, Writing - Review \& Editing, Supervision; KS: visualization, data presentation; SK: Critical review, revision and analysis.

\section{ORCID}

Lalit Chandravanshi : 0000-0002-0425-6797

\section{References}

[1] Agency for Toxic Substances and Disease Registry (ATSDR), Syracuse Research Corporation (SRC Inc). (2008). Draft toxicological profile for cadmium. U.S. Department of Health and Human Services, Public Health Service, Agency for Toxic Substances and Disease Registry; 2008.

[2] Ciesielski T, Weuve J, Bellinger DC, Schwartz J, Lanphear B, Wright RO. Cadmium exposure and neurodevelopmental outcomes in U.S. children. Environ Health Perspect 2012;120(5):758-763.

[3] Cao Y, Chen A, Radcliffe J, Dietrich KN, Jones RL, Caldwell K, et al. Postnatal cadmium exposure, neurodevelopment, and blood pressure in children at 2, 5, and 7 years of age. Environ Health Perspect 2009;117(10):1580-1586.

[4] Blasco J, Gomes T, García-Barrera T, Rodríguez-Romero A, Gonzalez-Rey M, Morán-Roldán F, et al. Trace metal concentrations in sediments from the south west of the Iberian. Peninsula Sci Mar 2010;74:99-106.

[5] Faroon O, Ashizawa A, Wright S, Tucker P, Jenkins K, Ingerman L, et al. Toxicological Profile for Cadmium. Agency for Toxic Substances and Disease Registry (US); 2012. 
[6] Ashraf MW. Levels of heavy metals in popular cigarette brands and exposure to these metals via smoking. Scientific World Journal. 2012; 2012:729430.

[7] International Agency for Research on Cancer (IARC) Cadmium and cadmium compounds, vol.100C; 2012

[8] Rahman MM, Asaduzzaman M, Naidu RJ. Consumption of arsenic and other elements from vegetables and drinking water from an arsenic-contaminated area of Bangladesh. Hazard Mater 2013;262:1056-1063.

[9] Watanabe T, Nakatsuka H, Shimbo S, Yaginuma-Sakurai K, Ikeda M. High cadmium and low lead exposure of children in Japan. Int Arch Occup Environ Health 2013;86(8):865-873.

[10] Interdonato M, Bitto A, Pizzino G, Irrera N, Pallio G, Mecchio A, et al. Levels of heavy metals in adolescents living in the industrialised area of Milazzo-Valle del Mela (northern Sicily). J Environ Public Health 2014:326845.

[11] Rebeniak M, Wojciechowska-Mazurek M, Mania M, Szynal T, Strzelecka A, Starska K. Exposure to lead and cadmium released from ceramics and glassware intended to come into contact with food. Rocz Panstw Zakl Hig 2014;65(4):301309.

[12] Taylor CM, Golding J, Emond AM. Moderate Prenatal Cadmium Exposure and Adverse Birth Outcomes: a Role for Sex-Specific Differences? Paediatr Perinat Epidemiol 2016;30(6):603-611.

[13] Ikeda M, Nakatsuka H, Watanabe T, Shimbo S. Estimation of dietary intake of cadmium from cadmium in blood or urine in East Asia. J Trace Elem Med Biol 2018;50:24-27.

[14] Khabour OF, Alzoubi KH, Al-Sheyab NA, Azab MA, Massadeh AM, Alomary AA, et al. Plasma and saliva levels of three metals in waterpipe smokers: a case control study. Inhal Toxicol 2018;30(6),224-228.

[15] Filippini T, Upson K, Adani G, Malagoli C, Baraldi C, Michalke B, et al. Comparison of Methodologies to Estimate Dietary Cadmium Intake in an Italian Population. Int J Environ Res Public Health. 2020;17(7):2264

[16] Waalkes MP. Cadmium carcinogenesis in review. J Inorg Biochem 2000;79(1-4):241-244..

[17] Järup L, Akesson A. Current status of cadmium as an environmental health problem. Toxicol Appl Pharmacol 2009;238(3):201-208.

[18] Alexandrov K, Rojas M, Satarug S. The critical DNA damage by benzo(a)pyrene in lung tissues of smokers and approaches to preventing its formation. Toxicol Lett 2010;198(1):63-68.

[19] Phuc HD, Kido T, Oanh NT1, Manh HD, Anh LT, Oyama Y, et al. Cadmium Exposure Is Associated with Monocyte Count and Monocyte to HDL Ratio, a Marker of Inflammation and Future Cardiovascular Disease in the Male Population. J Korean Med Sci 2017;32:1415-1422.

[20] Neslund-Dudas CM, McBride RB, Kandegedara A, Rybicki BA, Kryvenko ON, Chitale D, et al. Association between cadmium and androgen receptor protein expression differs in prostate tumors of African American and European American men. J Trace Elem Med Biol 2018;48:233-238.

[21] Noor N, Zong G, Seely EW, Weisskopf M, James-Todd T. Urinary cadmium concentrations and metabolic syndrome in U.S. adults: The National Health and Nutrition Examination Survey 2001-2014. Environ Int 2018;121:349-356.

[22] Gundacker C, Hengstschläger M. The role of the placenta in fetal exposure to heavy metals. Wien Med Wochenschr 2012;162(9-10):201-206.

[23] Perera F, Herbstman J. Prenatal environmental exposures, epigenetics, and disease Reprod Toxicol 2011;31(3):363-373.

[24] World Health Organization (WHO). Evaluation of certain food additives and contaminants. World Health Organ Tech Rep Ser 2011;(966):1-136.

[25] Cho YA, Kim J, Woo HD, Kang M. Dietary cadmium intake and the risk of cancer: a meta-analysis. PLoS One 2013;8(9):e75087.

[26] Goudarzi MA, Parsaei P, Nayebpour F, Rahimi E. Determination of mercury, cadmium and lead in human milk in Iran. Toxicol Ind Health 2013;29(9):820-823. 
[27] Næss S, Aakre I, Lundebye AK, Ørnsrud R, Kjellevold M, Markhus MW, et al. Mercury, lead, arsenic, and cadmium in Norwegian seafood products and consumer exposure. Food Addit Contam Part B 2020;1-8.

[28] Sun H, Chen W, Wang D, Jin Y, Chen X, Xu Y. The effects of prenatal exposure to low - level cadmium, lead and selenium on birth outcomes. Chemosphere 2014;108:33-39.

[29] Johnston JE, Valentiner E, Maxson P, Miranda ML, FryRC. Maternal Cadmium Levels during Pregnancy Associated with Lower Birth Weight in Infants in a North Carolina Cohort. PLoS One 2014;9(10):e109661.

[30] Dursun A, Yurdakok K, Yalcin SS, Tekinalp G, Aykut O, Orhan G4, et al. Maternal risk factors associated with lead, mercury and cadmium levels in umbilical cord blood, breast milk and newborn hair. J Matern Fetal Neonatal Med 2016;29(6):954-961.

[31] Luo Y, McCullough LE, Tzeng JY, Darrah T, Vengosh A, Maguire RL, et al. Maternal blood cadmium, lead and arsenic levels, nutrient combinations, and offspring birthweight. BMC Public Health 2017;17(1):354.

[32] Al-Saleh I, A-Rouqi R, Obsum CA, Shinwari N, Mashhour A, Billedo G, et al. Interaction between cadmium (Cd), selenium (Se) and oxidative stress biomarkers in healthy mothers and its impact on birth anthropometric measures. Int J Hyg Environ Health 2015;218(1):66-90.

[33] Wang F, Fan F, Wang L, Ye W, Zhang Q, Xie S. Maternal Cadmium Levels During Pregnancy and the Relationship with Preeclampsia and Fetal Biometric Parameters. Biol Trace Elem Res 2018;186(2):322-329.

[34] Kippler M, Tofail F, Hamadani JD, Gardner RM, Grantham-McGregor SM, Bottai M, et al. Early-life cadmium exposure and child development in 5-year-old girls and boys: a cohort study in rural Bangladesh. Environ Health Perspect 2012;120:1462-1468

[35] Gona S, Sanders AP, Miranda ML, Fry RC. Prenatal exposure to cadmium and cotinine and CpG island DNA methylation in mother-infant pairs. Genom Data 2015;5:378-380.

[36] Mohanty AF, Farin FM, Bammler TK, MacDonald JW, Afsharinejad Z, Burbacher TM, et al. Infant sex-specific placental cadmium and DNA methylation associations. Environ Res A 2015;138:74-81.

[37] Jeong KS, Park H, Ha E, Hong YC, Ha M, Park H, et al. Performance IQ in children is associated with blood cadmium concentration in early pregnancy. J Trace Elem Med Biol 2015;30:107-111.

[38] Viaene MK, Masschelein R, Leenders J, De Groof M, Swerts LJ, Roels HA. Neurobehavioural effects of occupational exposure to cadmium: a cross sectional epidemiological study Occup Environ Med 2000;57(1):19-27.

[39] Kordas K, Ardoino G, Coffman DL, Queirolo EI, Ciccariello D, Mañay N, et al. Patterns of Exposure to Multiple Metals and Associations with Neurodevelopment of Preschool Children from Montevideo, Uruguay. J Environ Public Health 2015;493471.

[40] Sanders AP, Claus Henn B, Wright RO. Perinatal and Childhood Exposure to Cadmium, Manganese, and Metal Mixtures and Effects on Cognition and Behavior: A Review of Recent Literature. Curr Environ Health Rep 2015;2(3):284-294.

[41] Johri, N, Jacquillet, G, Unwin, R (2010) Heavy metal poisoning: the effects of cadmium on the kidney. BioMetals 23:783792.

[42] Nawrot TS, Staessen JA, Roels HA, Munters E, Cuypers A, Richart T, et al. Cadmium exposure in the population: from health risks to strategies of prevention. Biometals 2010;23(5):769-782.

[43] Thevenod F, Lee WK Toxicology of cadmium and its damage to mammalian organs. Met Ions Life Sci 2013;11:415-490.

[44] Baek K, Chung I Cadmium Exposure Is Associated with Monocyte Count and Monocyte to HDL Ratio, a Marker of Inflammation and Future Cardiovascular Disease in the Male Population. J Korean Med Sci 2017;32(9):1415-1422.

[45] Hawkesworth S, Wagatsuma Y, Kippler M, Fulford AJ, Arifeen SE, Persson LA, et al. Early exposure to toxic metals has a limited effect on blood pressure or kidney function in later childhood, rural Bangladesh Int J Epidemiol 2013;42(1):176-185. 
[46] Barouki R, Gluckman PD, Grandjean P, Hanson M, Heindel JJ. Developmental origins of non-communicable disease: Implications for research and public health. Environ Health 2012;11(1):1-9

[47] Kantola M, Purkunen R, Kröger P, Tooming A, Juravskaja J, Pasanen M, et al. Accumulation of cadmium, zinc, and copper in maternal blood and developmental placental tissue: differences between Finland, Estonia, and St. Petersburg. Environ Res 2000;83(1):54-66.

[48] Wang H, Wang Y, Bo QL, Ji YL, Liu L, Hu YF, et al. Maternal cadmium exposure reduces placental zinc transport and induces fetal growth restriction in mice. Reprod Toxicol 2016;63:174-182.

[49] Xiong YW, Zhu HL, Nan Y, Cao XL, Shi XT, Yi SJ, et al. Maternal cadmium exposure during late pregnancy causes fetal growth restriction via inhibiting placental progesterone synthesis. Ecotoxicol Environ Saf. 2020;187:109879.

[50] Menai M, Heude B, Slama R, Forhan A, Sahuquillo J, Charles MA, et al. Association between maternal blood cadmium during pregnancy and birth weight and the risk of fetal growth restriction: the EDEN mother-child cohort study. Reprod Toxicol 2012;34(4):622-627.

[51] Al-Saleh I, Shinwari N, Mashhour A, Rabah A. Birth outcome measures and maternal exposure to heavy metals (lead, cadmium and mercury) in Saudi Arabian population. Int J Hyg Environ Health 2014;217(2-3):205-218.

[52] Tian LL, Zhao YC, Wang XC, Gu JL, Sun ZJ, Zhang YL, et al. Effects of gestational cadmium exposure on pregnancy outcome and development in the offspring at age 4.5 years. Biol Trace Elem Res 2009;132(1-3):51-59.

[53] Lin CM, Doyle P, Wang D, Hwang YH, Chen PC. Does prenatal cadmium exposure affect fetal and child growth? Occup Environ Med 2011;68(9):641-646.

[54] Chatzi L, Ierodiakonou D, Margetaki K, Vafeiadi M, Chalkiadaki G, Roumeliotaki T, et al. Prenatal Exposure to Cadmium and Child Growth, Obesity and Cardiometabolic Traits. Am J Epidemiol 2018;188(1):141-150.

[55] Olszowski T, Baranowska-Bosiacka I, Rębacz-Maron E, Gutowska I, Jamioł D, Prokopowicz A, et al.Cadmium Concentration in Mother's Blood, Milk, and Newborn's Blood and Its Correlation with Fatty Acids, Anthropometric Characteristics, and Mother's Smoking Status. Biol Trace Elem Res 2016;174(1):8-20.

[56] Cheng L, Zhang B, Zheng T, Hu J, Zhou A., Bassig B, et al. Critical Windows of Prenatal Exposure to Cadmium and Size at Birth. Int J Environ Res Public Health 2017;14(1):58.

[57] Zeng Z, Huo X, Zhang Y, Hylkema MN, Wu Y, Xu X. Differential DNA methylation in newborns with maternal exposure to heavy metals from an e-waste recycling area. Environ Res 2019;171:536-545.

[58] Cheng TF, Choudhuri S, Muldoon-Jacobs K. Epigenetic targets of some toxicologically relevant metals: a review of the literature. J Appl Toxicol 2012;32(9):643-653.

[59] Vidal AC, Semenova V, Darrah T, Vengosh A, Huang Z, King K, et al. Maternal cadmium, iron and zinc levels, DNA methylation and birth weight. BMC Pharmacol Toxicol 2015; 16(1):20.

[60] Ajayi OO, Charles-Davies MA, Arinola OG. Progesterone, selected heavy metals and micronutrients in pregnant Nigerian women with a history of recurrent spontaneous abortion. Afr Health Sci 2012;12(2):153-159.

[61] Ashley-Martin J, Dodds L, Arbuckle TE, Ettinger AS, Shapiro GD, Fisher M, et al. Maternal and cord blood manganese (Mn) levels and birth weight: The MIREC birth cohort study. Int J Hyg Environ Health 2018;221(6):876-882.

[62] Huang K, Li H, Zhang B, Zheng T, Li Y, Zhou A, et al. Prenatal cadmium exposure and preterm low birth weight in China J Expo Sci Environ Epidemiol 2017;27(5):491-496.

[63] Röllin HB, Kootbodien T, Channa K, Odland JØ. Prenatal Exposure to Cadmium, Placental Permeability and Birth Outcomes in Coastal Populations of South Africa. PLoS One 2015;10(11):e0142455

[64] Dharmadasa P, Kim N, Thunders M. Maternal cadmium exposure and impact on foetal gene expression through methylation changes. Food Chem Toxicol 2017;109:714-720.

[65] Al Omairi NE, Radwan OK, Alzahrani YA, Kassab RB. Neuroprotective efficiency of Mangifera indica leaves extract on cadmium-induced cortical damage in rats. Metab Brain Dis 2018;33(4):1121-1130. 
[66] Petersson Grawé K, Pickova J, Dutta PC, Oskarsson A. Fatty acid alterations in liver and milk of cadmium exposed rats and in brain of their suckling offspring. Toxicol Lett 2004;148(1-2):73-82.

[67] Osman K, Akesson A, Berglund M, Bremme K, Schütz A, Ask K, et al. Toxic and essential elements in placentas of Swedish women. Clin Biochem 2000;33:131-138.

[68] Kippler M, Bottai M, Georgiou V, Koutra K, Chalkiadaki G, Kampouri M, et al. Impact of prenatal exposure to cadmium on cognitive development at preschool age and the importance of selenium and iodine. Eur J Epidemiol 2016;31(11):1123-1134.

[69] Zhou T, Guo J, Zhang J, Xiao H, Qi X, Wu C, et al. Sex-Specific Differences in Cognitive Abilities Associated with Childhood Cadmium and Manganese Exposures in School-Age Children: a Prospective Cohort Study. Biol Trace Elem Res. 2020;193(1):89-99

[70] Szkup-Jabłońska M, Karakiewicz B, Grochans E, Jurczak A, Nowak-Starz G, Rotter I, et al Effects of blood lead and cadmium levels on the functioning of children with behaviour disorders in the family environment. Ann Agric Environ Med 2012;19(2):241-246.

[71] Jin L, Zhang L, Li Z, Liu JM, Ye R, Ren A. Placental concentrations of mercury, lead, cadmium, and arsenic and the risk of neural tube defects in a Chinese population. Reprod Toxicol 2013;35:25-31.

[72] Wright RO, Amarasiriwardena C, Woolf AD, Jim R, Bellinger DC. Neuropsychological correlates of hair arsenic, manganese, and cadmium levels in school-age children residing near a hazardous waste site. Neurotoxicology 2006;27:210-216.

[73] Rodríguez-Barranco M, Lacasaña M, Gil F, Lorca A, Alguacil J, Rohlman DS, et al. Cadmium exposure and neuropsychological development in school children in southwestern Spain. Environ Res 2014;134:66-73.

[74] Gustin K, Tofail F, Vahter M, Kippler M. Cadmium exposure and cognitive abilities and behavior at 10 years of age: A prospective cohort study. Environ Int 2018;113:259-268.

[75] Marlowe M, Stellern J, Errera J, Moon C. Main and interaction effects of metal pollutants on visual-motor performance. Arch Environ Health 1985;40(4):221-225.

[76] Wang H, Dumont X, Haufroid V, Bernard A. The physiological determinants of low-level urine cadmium: an assessment in a cross-sectional study among schoolchildren. Environ Health 2017;16(1):99.

[77] Jiang HM, Han GA, He ZL. Clinical significance of hair cadmium content in the diagnosis of mental retardation of children. Chin Med J (Engl)1990;103(4):331-334.

[78] Capel ID, Pinnock MH, Dorrell HM, Williams DC, Grant EC. Comparison of concentrations of some trace, bulk, and toxic metals in the hair of normal and dyslexic children. Clin Chem 1981;27(6):879-881.

[79] Bao QS, Lu CY, Song H, Wang M, Ling W, Chen WQ, et al. Behavioural development of school-aged children who live around a multi-metal sulphide mine in Guangdong province, China: a cross-sectional study. BMC Public Health 2009;9(1):1-8.

[80] Kippler M, Nermell B, Hamadani J, Tofail F, Moore S, Vahter M, et al. Burden of cadmium in early childhood: longitudinal assessment of urinary cadmium in rural Bangladesh. Toxicol Lett 2010;198(1):20-25.

[81] Sioen I, Den Hond E, Nelen V, Van de Mieroop E, Croes K, Van Larebeke N, et al. Prenatal exposure to environmental contaminants and behavioural problems at age 7-8years. Environ Int. 2013;59:225-31

[82] Kim Y, Ha EH, Park H, Ha M, Kim Y, Hong YC, et al. Prenatal lead and cadmium co-exposure and infant neurodevelopment at 6 months of age: the Mothers and Children's Environmental Health (MOCEH) study. Neurotoxicology 2013;35:15-22.

[83] Forns J, Fort M, Casas M, Cáceres A, Guxens M, Gascon M, et al. Exposure to metals during pregnancy and neuropsychological development at the age of 4 years. Neurotoxicology 2014;40:16-22.

[84] Schantz SL1, Widholm JJ. Cognitive effects of endocrine-disrupting chemicals in animals. Environ Health Perspect 2001;109(12):1197-1206. 
[85] Takiguchi M, Yoshihara S. New aspects of cadmium as endocrine disruptor. Environ Sci 2006;13(2):107-116.

[86] Vahter M, Akesson A, Liden C, Ceccatelli S, Berglund M. Gender differences in the disposition and toxicity of metals. Environ Re. 2007;104(1):85-95.

[87] Minetti A, Reale CA. Sensorimotor developmental delays and lower anxiety in rats prenatally exposed to cadmium. J Appl Toxicol 2006;26(1):35-41.

[88] Ishitobi H, Mori K, Yoshida K, Watanabe C, et al. Effects of perinatal exposure to low-dose cadmium on thyroid hormone-related and sex hormone receptor gene expressions in brain of offspring. Neurotoxicology 28(4):790-797.

[89] Robinson JF, Yu X, Hong S, Zhou C, Kim N, DeMasi D, et al. Embryonic toxicokinetic and dynamic differences underlying strain sensitivity to cadmium during neurulation. Reprod Toxicol 2010;29(3):279-285.

[90] Robinson JF, Yu X, Hong S, Griffith WC, Beyer R, Kim E, et al. Cadmium-induced differential toxicogenomic response in resistant and sensitive mouse strains undergoing neurulation. Toxicol Sci 2009;107(1):206-219.

[91] Waalkes MP. Effect of dietary zinc deficiency on the accumulation of cadmium and metallothionein in selected tissues of the rat. J Toxicol Environ Health 1986;18(2):301-313.

[92] Rigon AP, Cordova FM, Oliveira CS, Posser T, Costa AP, Silva IG, et al. Neurotoxicity of cadmium on immature hippocampus and a neuroprotective role for p38 MAPK. Neurotoxicol 2008;29(4):727-734

[93] Chemek M, Boughammoura S, Mimouna SB, Chouchene L, Banni M, Messaoudi I. Changes of the mRNA expression pattern of $\mathrm{Zn}$ transporters: a probable mechanism for cadmium retention and zinc redistribution in the suckling rat tissues. Biol Trace Elem Res 2015;165(2):173-182.

[94] Dési I, Nagymajtényi L, Schulz H. Behavioural and neurotoxicological changes caused by cadmium treatment of rats during development. J Appl Toxicol 1998;18(1):63-70.

[95] Paniagua-Castro N, Escalona-Cardoso G, Chamorro-Cevallos G. Glycine reduces cadmium-induced teratogenic damage in mice. Reprod Toxicol 2007;23(1):92-97.

[96] Zhang YM, Liu XZ, Lu H, Mei L, Liu ZP. Lipid peroxidation and ultrastructural modifications in brain after perinatal exposure to lead and/or cadmium in rat pups. Biomed Environ Sci 22(5):423-429.

[97] Shahbazian MD, Zoghbi HY. Rett syndrome and MeCP2: linking epigenetics and neuronal function," American Journal of Human Genetics 2002;71(6):1259-1272.

[98] Lafuente A, Cano P, Esquifino A. Are cadmium effects on plasma gonadotropins, prolactin, ACTH, GH and TSH levels, dose-dependent?" Biometals 2003;16(2):243-250.

[99] Lafuente A, González-Carracedo A, Romero A, Cano P, Esquifino AI. Cadmium exposure differentially modifies the circadian patterns of norepinephrine at the median eminence and plasma LH, FSHand testosterone levels. Toxicol Lett. 2004;146:175-182.

[100] Papp A, Oszlánczi G, Horváth E, Paulik E, Kozma G, Sápi A, et al. Consequences of subacute intratracheal exposure of rats to cadmium oxide nanoparticles: electrophysiological and toxicological effects. Toxicol Ind Health 2012;28(10):933-941.

[101] Bitto A, Pizzino G, Irrera N1, Galfo F, Squadrito F. Epigenetic modifications due to heavy metals exposure in children living in polluted areas. Curr Genomics. 2014;15(6):464-468.

[102] Schoeters G, Den Hond E, Zuurbier M, Naginiene R, van den Hazel P, Stilianakis N, et al. Cadmium and children: exposure and health effects. Acta Paediatr Suppl 2006;95:50-54.

[103] Jayatilake N, Mendis S, Maheepala P, Mehta FR. Chronic kidney disease of uncertain aetiology: prevalence and causative factors in a developing country BMC Nephrology 2013;14(1):180.

[104] Nordberg G, Jin T, Wu X, Lu J, Chen L, Liang Y, et al. Kidney dysfunction and cadmium exposure--factors influencing dose-response relationships. J Trace Elem Med Biol 2012;26(2-3):197-200. 
[105] Jean J, Sirot V, Hulin M, Le Calvez E, Zinck J, Noël L, et al Dietary exposure to cadmium and health risk assessment in children - Results of the French infant total diet study. Food Chem Toxicol 2018;115:358-364.

[106] Trzcinka-Ochocka M, Jakubowski M, Razniewska G, Halatek T, Gazewski A; The effects of environmental cadmium exposure on kidney function: the possible influence of age. Environ Res 2004;95(2):143-150.

[107] Bernard A. Renal dysfunction induced by cadmium: biomarkers of critical effects. Biometals 2004;17(5):519-523.

[108] de Burbure C, Buchet JP, Leroyer A, Nisse C, Haguenoer JM, Mutti A, et al. Renal and Neurologic Effects of Cadmium, Lead, Mercury, and Arsenic in Children: Evidence of Early Effects and Multiple Interactions at Environmental Exposure Levels. Environ Health Perspect 2006;114(4):584-590.

[109] Jacobo-Estrada T, Santoyo-Sánchez M, Thévenod F, Barbier O Tania. Cadmium Handling, Toxicity and Molecular Targets Involved during Pregnancy: Lessons from Experimental Models. Int J Mol Sci 2017;18(7):1590.

[110] Li L, Dong F, Xu D, Du L, Yan S, Hu H, et al. Short-term, low-dose cadmium exposure induces hyperpermeability in human renal glomerular endothelial cells. J Appl Toxicol 2016;36(2):257-265.

[111] Bernard AM, Vyskocil A, Roels H, Kriz J, Kodl M, Lauwerys R. Renal effects in children living in the vicinity of a lead smelter. Environ Res 1995;68(2):91-95.

[112] Bernard A, Thielemans N, Roels H, Lauwerys R. Association between NAG-B and cadmium in urine with no evidence of a threshold. Occup Environ Med 1995;52(3):177-180.

[113] Verberk MM, Willems TE, Verplanke AJ, de Wolff FA. Environmental lead and renal effects in children. Arch Environ Health 1996;51(1):83-87.

[114] Chen X, Zhou H, Li X, Wang Z, Zhu G, Jin T. Effects of lead and cadmium co-exposure on hemoglobin in a Chinese population. Environ Toxicol Pharmacol. 2015;39(2):758-763.

[115] Wanigasuriya K, Jayawardene I, Amarasiriwardena C, Wickremasinghe R. Novel urinary biomarkers and their association with urinary heavy metals in chronic kidney disease of unknown aetiology in Sri Lanka: a pilot study. Ceylon Med J 2017;62:210-217.

[116] Zachwieja K, Korohoda P, Kwinta-Rybicka J, Miklaszewska M, Moczulska A, Bugajska J, et al. Which equations should and which should not be Employed in calculating egfr in children? Adv Med Sci 2014;60(1):31-40.

[117] Ikeda M, Shimbo S, Watanabe T, Ohashi F, Fukui Y, Sakuragi S, et al. Estimation of Dietary Pb and Cd Intake from Pb and Cd in Blood or Urine. Biol Trace Elem Res 2010;139(3):269-286

[118] Cabral M, Toure A, Garçon G, Diop C, Bouhsina S, Dewaele D, et al. Effects of environmental cadmium and lead exposure on adults neighboring a discharge: Evidences of adverse health effects. Environ Pollut 2015;206:247-255.

[119] Fucic A, Plavec D, Casteleyn L, Aerts D, Biot P, Katsonouri A, et al. Gender differences in cadmium and cotinine levels in prepubertal children. Environ Res, 2015;141:125-131.

[120] Ferraro PM, Costanzi S, Naticchia A, Sturniolo A, Gambaro G. Low level exposure to cadmium increases the risk of chronic kidney disease: analysis of the NHANES 1999-2006. BMC Public Health 2010;10(1):304.

[121] Skröder H, Hawkesworth S, Kippler M, El Arifeen S, Wagatsuma Y, Moore SE, et al. Kidney function and blood pressure in preschool-aged children exposed to cadmium and arsenic--potential alleviation by selenium. Environ Res 2015;140:205-213.

[122] Weaver VM, Vargas GG, Silbergelda EK, Rothenberg SJ, Fadrowski JJ, Rubio-Andraded M, et al. Impact of urine concentration adjustment method on associations between urine metals and estimated glomerular filtration rates (eGFR) in adolescents. Environ Res 2014;132:226-232.

[123] Swaddiwudhipong W, Mahasakpan P, Jeekeeree W, Funkhiew T, Sanjum R, Apiwatpaiboon T, et al. Renal and blood pressure effects from environmental cadmium exposure in Thai children. Environ Res 2015;136:82-87.

[124] Aoshima K. Itai-itai disease: cadmium-induced renal tubular osteomalacia. Nihon Eiseigaku Zasshi 2012;67(4):455463. 
[125] Noonan CW, Sarasua SM, Campagna D, Kathman SJ, Lybarger JA, Mueller PW; Effects of exposure to low levels of environmental cadmium on renal biomarkers. Environ Health Perspect 2002;110(2):151-155.

[126] Nikic D, Stankovic A, Nikolic M, Bogdanovic D, Petrovic B. Estimated daily intake of cadmium by children living in the city of Nis, Serbia. Turk J Pediatr 2009;51:257-263.

[127] Ruiz P, Mumtaz M, Osterloh J, Fisher J, Fowler BA. Interpreting NHANES biomonitoring data, cadmium. Toxicol Lett 2010;198(1):44-48.

[128] Saillenfait AM, Payan JP, Brondeau MT, Zissu D, de Ceaurriz J. Changes in urinary proximal tubule parameters in neonatal rats exposed to cadmium chloride during pregnancy. J Appl Toxicol 1991;11(1):23-27.

[129] Saillenfait AM, Payan JP, Ban M, de Ceaurriz J. Indirect and lactation-associated changes in renal alkaline phosphatase of newborn rats prenatally exposed to cadmium chloride. J Appl Toxicol 1992;12(3):205-210.

[130] Jacquillet G, Barbier O, Rubera I, Tauc M, Borderie A, Namorado MC, et al. Cadmium causes delayed effects on renal function in the offspring of cadmium-contaminated pregnant female rats. Am J Physiol Renal Physiol 2007;293(5):F1450-F1460.

[131] García GG, Nandini S, Sarma SS. Effect of cadmium on the population dynamics of Moina macrocopa and Macrothrix triserialis (Cladocera). Bull Environ Contam Toxicol 2004;72(4):717-724.

[132] Vaidya VS, Waikar SS, Ferguson MA, Collings FB, Sunderland K, Gioules C, et al. Urinary biomarkers for sensitive and specific detection of acute kidney injury in humans. Clin Transl Sci 1(3):200-208.

[133] Prozialeck WC, Edwards JR, Vaidya VS, Bonventre JV. Preclinical evaluation of novel urinary biomarkers of cadmium nephrotoxicity. Toxicol Appl Pharmacol 2009;238(3):301-305.

[134] Lee YK, Park EY, Kim S, Son JY, Kim TH, Kang WG, et al. Evaluation of cadmium-induced nephrotoxicity using urinary metabolomic profiles in sprague-dawley male rats. J Toxicol Environ Health A 77(22-24):1384-1398.

[135] Blum JL, Edwards JR, Prozialeck WC, Xiong JQ, Zelikoff JT. Effects of Maternal Exposure to Cadmium Oxide Nanoparticles During Pregnancy on Maternal and Offspring Kidney Injury Markers Using a Murine Model. J Toxicol Environ Health A 2015;78(12):711-724.

[136] International Agency for Research on Cancer (IARC). International Agency for Research on Cancer Monographs on the Eval-uation of Carcinogenic Risks to Humans. IARC Scientific Publications; 1993. 119-237.

[137] Stayner L, Smith R, Thun M, Schnorr T, Lemen R. A quantitative assessment of lung cancer risk and occupational cadmium exposure. IARC Sci Pub 1992;118:447-455.

[138] Van der Gulden JW, Kolk JJ, Verbeek AL. Work environment and prostate cancer risk. Prostate. 1995;27(5):250-257.

[139] Pesch B, Haerting J, Ranft U, Klimpel A, Oelschlägel B, Schill W. Occupational risk factors for renal cell carcinoma: agent-specific results from a case-control study in Germany. MURC Study Group. Multicenter urothelial and renal cancer study. Int J Epidemiol 2000;29(6):1014-1024.

[140] Wei XL, He JR, Cen YL, Su Y, Chen LJ, Lin Y, et al. Modified effect of urinary cadmium on breast cancer risk by selenium. Clin Chim Acta 2015;438:80-85.

[141] Infante-Rivard C, Olson E, Jacques L, Ayotte P. Drinking water contaminants and childhood leukemia. Epidemiology 2001;12(1):13-19.

[142] Absalon D, Slesak B; The effects of changes in cadmium and lead air pollution on cancer incidence in children. Sci Total Environ 2010;408(20):4420-4428.

[143] Sherief LM, Abdelkhalek ER, Gharieb AF, Sherbiny HS, Usef DM, Almalky MA, et al. Cadmium status among pediatric cancer patients in Egypt. Medicine 2015;94(20):e740.

[144] Kriegel AM, Soliman AS, Zhang Q, El-Ghawalby N, Ezzat F, Soultan A, et al. Serum cadmium levels in pancreatic cancer patients from the East Nile Delta region of Egypt. Environ Health Perspect 2006;114(1):113-119. 
[145] Huff J, Lunn RM, Waalkes MP, Tomatis L, Infante PF. Cadmium-induced cancers in animals and in humans. Int J Occup Environ Health 2017;13(2):202-212.

[146] Lin YS, Caffrey JL, Lin JW, Bayliss D, Faramawi MF, Bateson TF, et al. Increased risk of cancer mortality associated with cadmium exposures in older americans with low zinc intake Journal of Toxicology and Environmental Health Part A 2013;76(1):1-15.

[147] Motykiewicz G, Perera FP, Santella RM, Hemminki K, Seemayer NH, Chorazy M. Assessment of cancer hazard from environmental pollution in Silesia. Toxicol Lett 1996;88(1-3):169-173.

[148] Ruchirawat M, Settachan D, Navasumrit P, Tuntawiroon J, Autrup H. Assessment of potential cancer risk in children exposed to urban air pollution in Bangkok, Thailand. Toxicol Lett 2007;168(3):200-209.

[149] Akesson A, Berglund M, Schutz A, Bjellerup P, Bremme K, Vahter M. Cadmium exposure in pregnancy and lactation in relation to iron status. Am J Public Health 2002;92(2):284-287.

[150] Silver MK, Lozoff B, Meeker JD. Blood cadmium is elevated in iron deficient U.S. children: a cross-sectional study. Environ Health 2013;12(1):117.

[151] Satarug S, Moore MR. Adverse Health Effects of Chronic Exposure to Low-Level Cadmium in Foodstuffs and Cigarette Smoke. Environ Health Perspect 112(10):1099-1103.

[152] Fenton SE, Reed C, Newbold RR. Perinatal Environmental Exposures Affect Mammary Development, Function, and Cancer Risk in Adulthood. Annu Rev Pharmacol Toxicol 2012;52:455-479.

[153] Davis J, Khan G, Martin MB, Hilakivi-Clarke L. Effects of maternal dietary exposure to cadmium during pregnancy on mammary cancer risk among female offspring. J Carcinog 2013;12:11.

[154] Prins GS. Endocrine disruptors and prostate cancer risk. Endocr Relat Cancer 2008;15:649-56.

[155] Gallagher CM, Chen JJ, Kovach JS. Environmental cadmium and breast cancer risk. Aging 2010;2(11):804-814.

[156] López E, Arce C, Oset-Gasque MJ, Cañadas S, González MP. Cadmium induces reactive oxygen species generation and lipid peroxidation in cortical neurons in culture. Free Radic Biol Med 2006;40(6):940-951.

[157] Anetor JI. Rising environmental cadmium levels in developing countries: threat to genome stability and health. Niger J Physiol Sci 2012;27(2):103-15.

[158] Ghosh K, N I. Cadmium treatment induces echinocytosis, DNA damage, inflammation, and apoptosis in cardiac tissue of albino Wistar rats. Environ Toxicol Pharmacol 2018;59:43-52.

[159] Joseph P. Mechanisms of cadmium carcinogenesis. Toxicol Appl Pharmacol 2009;238(3):272-279.

[160] Siewit CL, Gengler B, Vegas E, Puckett R, Louie MC. Cadmium promotes breast cancer cell proliferation by potentiating the interaction between ERalpha and c-Jun. Mol Endocrinol 2010;24(5):981-992.

[161] Garrett SH, Somji S, Sens MA, Zhang K, Sens DA. Microarray analysis of gene expression patterns in human proximal tubule cells over a short and long time course of cadmium exposure. J Toxicol Environ Health A 2010;74(1):24-42.

[162] Arita A, Costa M. Epigenetics in metal carcinogenesis: nickel, arsenic, chromium and cadmium. Metallomics 2009;1(3):222-228.

[163] Długaszek M, Skrzeczanowski W. Relationships Between Element Contents in Polish Children's and Adolescents' Hair. Biol Trace Elem Res 2017;180(1):6-14.

[164] Forysová K, Pinkr-Grafnetterová A, Malý M, Krsková A, Mráz J, Kašparová L, et al. Urinary Cadmium and Cotinine Levels and Hair Mercury Levels in Czech Children and Their Mothers Within the Framework of the COPHES/DEMOCOPHES Projects. Arch Environ Contam Toxicol 2017;73(3):421-430.

[165] Zhou C, Zhang R, Cai X, Xiao R, Yu H. Trace elements profiles of maternal blood, umbilical cord blood, and placenta in Beijing, China. J Matern Fetal Neonatal Med 2017;32(11):1755-1761.

[166] Richter P, Faroon O, Pappas RS. Cadmium and Cadmium/Zinc Ratios and Tobacco-Related Morbidities. Int J Environ Res Public Health 2017;14(10):1154. 
[167] Zeng HL, Li H, Lu J, Guan Q, Cheng L. Assessment of 12 Metals and Metalloids in Blood of General Populations Living in Wuhan of China by ICP-MS. Biol Trace Elem Res 2018;189(2):344-353.

[168] Nriagu J, Boughanen M, Linder A, Howe A, Grant C, Rattray R, et al. Levels of As, Cd, Pb, Cu, Se and Zn in bovine kidneys and livers in Jamaica. Ecotoxicol Environ Saf 2009;72(2):564-571.

[169] Afridi HI, Kazi TG, Talpur FN, Kazi A, Arain SS, Arain SA. Interaction between essential elements selenium and zinc with cadmium and mercury in samples from hypertensive patients. Biol Trace Elem Res 2014;160(2):185-196. 